\title{
Illocutionary Act Found on Character Arthur Fleck's in Joker Movie
}

\author{
Luki Saptiko
}

Siti Musarokah

Th. Cicik Sophia Budiman ${ }^{3}$

${ }^{1}$ Corresponding author, English Education Department, University of PGRI Semarang, Semarang, Indonesia; lukiseptiko@gmail.com

${ }^{2}$ English Education Department, Language and Arts Education Faculty, University of PGRI Semarang, Semarang, Indonesia; musarokahsiti@yahoo.com

${ }^{3}$ English Education Department, Language and Arts Education Faculty, University of PGRI Semarang, Semarang, Indonesia; ciciksophia@ upgris.ac.id

Received: May 11, 2021 Accepted: July 15, $2021 \quad$ Published: July 28, 2021

\begin{abstract}
This study is focused on the illocutionary acts found on Arthur Fleck's dialogues in Joker (2019) movie. The objectives of this study are (1) to find out the types of illocutionary acts used by the character Arthur in Joker movie and (2) to find out the dominant types of illocutionary acts used by the character Arthur in Joker movie and what that means. To reach those objectives of study, the writers use Searle (2002) theory to conduct the study. There are five types of illocutionary acts according to Searle (2002). They are assertive, directive, commisive, expressive, and declarative. This study used qualitative design because it is framed in terms of using words instead of numbers. The result of data finding shows that there were 52 utterances done by Arthur Fleck indicating illocutionary acts. The illocutionary types found are assertive, directive, commissive, expressive, and declarative. There are 8 utterances categorized as assertives type, 27 utterances categorized as directives type, 4 utterances categorized as commissive type, 9 utterances categorized as expressives type, and 4 utterances categorized as declaratives type. Directive type is the dominant type found in Arthur's utterances
\end{abstract}

Keywords: Illocutionary Acts; Movie; Spoken text analysis

To cite this article: Sophia, T., Saptiko, L., \& Musarokah, S. (2021). Illocutionary act found on character Arthur Fleck's in Joker movie. SALEE: Study of Applied Linguistics and English Education, 2(2), 137-154. https://doi.org/10.35961/salee.v2i02.272 


\section{Introduction}

As a human being, communication is done through gestures, messages, and languages. A Chinese proverb said that if a man wants to know each other, use language to communicate. By means, language is a tool to communicate with each entity therefore they can understand each other. Language communication was divided into verbal and non-verbal communication. Hidayat (2016) describes verbal communication as the way of communicating messages by using words as elements. Nonverbal communication is the way of communicating messages by using gestures, body movements, eye contact, facial expression, or general appearances as the elements. Usually, to unfold the meaning in verbal communication, linguists use the study of speech acts.

Speech acts is a study in linguistic pragmatics to unfold the intended information in an individual's speech and performance. According to Martinez (2015), the speech act is an act of speaking, saying and knowing, an act of creation, of establishment of connections in the thing perceived, apprehended and purposefully transformed in its way of being, created in the conscience of the speaking, saying and knowing subject. Initially the thing perceived is sensitive and concrete, then it is transformed in its way of being and made abstract, mental and virtual; then it is made objective, true, and finally it is orientated to things in the world thus made real. Siritman (2020) also states that the speech act classifications comprise two (1) constative speech acts and (2) performative speech acts. The performative one is classified by Austin, into three types: locutionary acts, illocutionary acts, and perlocutionary acts.

A locutionary act, the performance of an utterance is the actual utterance and its apparent meaning, comprising any and all of its verbal, social, and rhetorical meanings, all of which correspond to the verbal, syntactic and semantic aspects of any meaningful utterance. Meanwhile an illocutionary act is the active result of the implied request or meaning presented by the locutionary act. For example, if the locutionary act in an interaction is the question "Is there any salt?" the implied illocutionary request is "Can someone pass the salt to me?". and in certain cases a further perlocutionary act is the actual effect of the locutionary and illocutionary acts, such as persuading, convincing, scaring, enlightening, inspiring, or otherwise getting someone to do or realize something, whether intended or not.

This scientific article focuses on revealing the illocutionary acts used by character Arthur in Joker movie. The writers choose this movie because it was got many awards from movie appreciation and also the writers are interested in the main character of this movie because he is not such a communicative person but when he starts talking, his utterance contains so many meanings. The writers want to know (1) The types of illocutionary acts used by the character Arthur in Joker movie and (2) The dominant types of illocutionary acts used by the character Arthur in Joker movie and what that means. The writers analyze Arthur's dialog script in Joker Movie. Therefore, this study uses descriptive qualitative research.

\section{Review of Literature}

\subsubsection{Previous Studies}

Before the writer took the topic, the writer found the topic which is related to the topic taken. The topic can be referential data. First, the writer found a previous study based on the objective of research which is an illocutionary act of research. The first previous study from 
Sembiring (2019) reported Illocutionary Acts on "Aladdin" Movie. The article aims of the research were to find out the types and the function of context of illocutionary act on Aladdin movie. It was a descriptive qualitative research. It was found the 30 utterances of illocutionary acts. The data were classified into five; directives, assertives, declaratives, commissives, and expressives. From 30 illocutionary acts, directives were the most frequent types of illocutionary act because the main characters mostly expressed their utterances in direct way such as by ordering, requesting, asking and commanding.

The second previous study from Petriandy (2018) reported Illocutionary Acts Found in "Novel the Never Girls: Before the Bell by Kiki Thorpe". The article aims to analyze types of illocutionary act found in novel The Never Girls Bell: Before the Bell by Kiki Thorpe. This research used the descriptive qualitative method. There are some types of illocutionary act in this paper; they are representative (informing, asserting, predicting, reporting); directive (asking, requesting, stating), commissive (promising); expressive (liking, complimenting), and declarative. The finding of the data has shown that in novel the highest is representative 28 data or about $50 \%$ and the highest representative type is informing. And the second is directive 21 data or about $37,5 \%$ and the highest directive is asking.

The third previous study from Emmiyati (2012) reported Illocutionary Acts in "Midnight in Paris" movie. The article aims to describe the types of illocutionary acts of main character in "Midnight in Paris" movie. It also aims to describe the type of illocutionary acts which is mostly used by the main character. It is a content analysis where the source of data is the "Midnight in Paris" movie directed by Woody Allen in 2011 which consisted of 245 utterances. The data are in the form of main character's 44 utterances and categorized into types of illocutionary acts based on Searle's theory. Based on the data analysis, the finding shows five types of illocutionary acts in main character's utterances, namely assertive, directive, commissive, declarative and expressive. Assertive is mostly used by the main character.

The fourth previous study from Rohmadi (2016) reported Illocutionary Acts on Speech of Foreign Students in Indonesian Learning. The study aims to describe the forms of illocution done by the Indonesian Language students. This is a qualitative study. Observation, interviews, and documentation methods are used to collect data. The data are the utterances containing illocutionary force (assertive, declaration, directives, commissive, and expressive) in learning activities. The data source in the research is the speech acts of a foreign student in Indonesian Language learning.

The fifth previous study from Hidayat (2020) reported Illocutionary Speech Acts Analysis in Tom Cruise's Interview. The study aims to describe the types as well as the functions of illocutionary speech acts performed by both the interviewer and the interviewee. The study uses qualitative method employing descriptive analysis design. The result showed that there are four kinds of illocutionary speech acts which are performed in Tom Cruise's interview which are representative, commissive, directive, and expressive. The percentage of the most performed or the most used speech acts to the least one in Tom Cruise's interview is: representative $(48.7 \%)$, expressive $(38.5 \%)$, commissive $(7.7 \%)$, directive $(5.1 \%)$, and declarative $(0 \%)$. 


\subsubsection{Review of Related Literature}

\subsubsection{Pragmatic}

Pragmatic is the study of language in contextual meaning and the study of the practical aspects of human action and thought. Pragmatic outlines the study of meaning in the interactional context. It looks beyond the literal meaning of an utterance and considers how meaning is constructed as well as focusing on implied meanings. According to Yule (2006) pragmatics is the study of "invisible" meaning, or how we recognize what is meant even when it is not actually said or written. In order to make it happen, speakers or writers must be able to depend on a lot of shared assumptions and expectations provides us with some insights into how more is always being communicated than is said. Mey (2001) states Pragmatics concern in the process of creating language and its producer, not just in the endproduct, language. This study is about what people assume and goal on what they are saying, the meaning of every word they utter.

\subsubsection{Speech Acts}

Speech acts is a "locomotive" to move a language or as a "trigger kit" to make a language functional in communication (Meilantina, 2020). According to Kent Bach (1985) speech act is the performance of several acts at once, distinguished by different aspects of the speaker's intention: there is the act of saying something, what one does in saying it, such as requesting or promising, and how one is trying to affect one's audience.

\section{a. Locutionary Act}

According to Riemer (2010), locutionary acts are called as the act of saying something. Yule (2000), this is the basic act of utterance or producing meaningful linguistic expression.

\section{b. Perlocutionary Act}

Riemer (2010) states that perlocutionary act is the act of producing an effect in the hearer by means of the utterance. Moreover Nadar (2003) describes that an utterance can cause the hearer to do something. In addition, perlocutionary acts are an act to influence the hearer such as, embarrassing, intimidating, persuading, and so on.

\section{c. Illocutionary Act}

Searle in Finch (2000) classifies the illocutionary acts into five types, namely (1) representative, (2) directive, (3) commissive, (4) expressive, and (5) declarative. Of the five types of illocutionary acts, four types of illocutionary acts are commonly used in communication practices. Yule (2000) depicts illocutionary act performed via communicative force of an utterance. The criteria of illocutionary acts are based on the contexts which determine the forces or functions of the utterances. Same utterances can be 
categorized as different illocutionary because of different forces or functions which are greatly influenced by context of use.

d. Representative

Representative refers to the acts which commit the speakers to the truth of the expressed proposition. These are kinds of speech acts that state what the speaker believes to be the case or not. Statements of fact, assertions, conclusions, as illustrated. Statement about the world, like describing, claiming, and concluding. In using representatives, the speaker makes words fit the world (of belief).

Example:

The earth is flat.

Chomsky didn't write about peanuts.

It was a warm sunny day.

e. Directive

In speaking, speakers often intend to get hearers to do something. In this case, the speakers have performed directive acts. Directive acts deal with an attempt of the speakers to get the hearer to do something through language. It expresses what the speakers want. Direct the hearer towards doing something, describing, asking, and requesting. In using a directive, the speaker attempts to make the world fit the words (via the hearer).

Example:

Gimme a cup of coffee. Make it black.

Could you lend me a pen, please?

Don't touch that.

\section{f. Commissive}

Commissives deal with the acts which commit the speakers to some future course of action. The commissive acts include promising, vowing, offering, threatening and refusing. Commissives are those kinds of speech acts that speakers use to commit themselves to some future action. They express what the speaker intends. They are promises, threats, refusals, pledges. In using a commissive, the speaker undertakes to make the world fit the words (via the speaker).

Example:

I'II be back. 
I'm going to get it right next time.

We will not do that.

\section{g. Expressive}

Speakers of a language often express feelings to the hearers when they speak. By doing so, the speaker has performed the expressive acts expressive refer to acts that are performed to express a psychological state of the speakers. Statement of pleasure, pain, like, dislike, joy and sorrow can be categorized into this act. Those are those kinds of speech acts that state what the speaker feels. In using expressive, the speakers make words fit the worlds (of feeling).

Example:
I'm really sorry!
Congratulations!
Oh, yes, great!

\section{h. Declarative}

The utterances produced in a particular context may be able to change the condition of the world immediately. Declaratives refer to the kind of speech acts that can change the world via utterances. In order to perform declaratives acts appropriately, some circumstances must be met including the speakers must be met including the speakers must have specific institutional roles and there must be specific context. These are those kinds of speech acts that change the world via their utterances. As the example illustrates, the speaker has to have a special institutional role, in a specific context, in order to perform a declaration appropriately. In using a declaration, the speaker changes the world via words.

\section{Example:}

Priest : I now pronounce you husband and wife.

Referce: You're out!

Jury : We find the defendant guilry.

\section{Method}

\subsection{Object}

The object of this study is Arthur Fleck from Joker (2019) movie. In this study, the writers analyze the scripts using Finch (2000) method of finding illocutionary act types in a text. First, the writers found out the types of illocutionary acts in each clause of the script. Then, the writers find the dominant types of illocutionary act types and then discuss what the dominant types found means. 


\subsection{Instrument}

The instruments of this research are Joker movie and the movie script. The writer got the movie and the script by downloading them on the internet. The writer used laptop as a tool to gain the script and the movie.

\subsection{Procedures}

To make sure the data was valid, the writers used observation methods for collecting the data. First, the writers watched the movie and read the script to make sure they were matched. Then, the writers made notes and classified the sentences that were related to illocutionary acts.

\subsection{Data analysis}

The method of data analysis is based on Finch (2000) method in finding illocutionary acts which are finding the five types of illocutionary acts. There are four steps in analyzing the data.

a. Collecting data transcripts of the dialogs by Arthur Fleck in Joker (2019) movie is the first step in data analysis. The writers downloaded the movie script from the internet. The movie was watched and the script was read to make sure they are truly matched.

b. Parting the transcripts into clauses is the second step in which the writers perform the textual analysis to support the statement of the problem but it will not release in answering the research findings. When parting the transcripts into clauses, the writers delete certain parts of the data. Miles \& Huberman (2014) stated what was done by the writers in this step was called data reduction. Miles \& Huberman explained that data reduction is possibly done when analyzing data as long as it does not cause significant loss of the information.

c. Identifying the illocutionary act types is the third step. This step is the core since its result is what the writer uses to draw an inference. After identifying the illocutionary act types, the fourth step is presenting the data. Presenting the data is also called data display. "Displays are used at all stages, since they enable data to be organized and summarized, they show what stage the analysis has reached and they are the basis for further analysis" Miles \& Huberman (2014).

d. Drawing the conclusion is the last step of data analysis. This is the result of the data analysis described in words. This is what answers all of the research problems. Miles \& Huberman (2014) states, "They are not finalized until all the data are in, and have 
been analyzed." From the statement it could be stated that all data compiled had been analyzed.

\section{Findings and Discussion}

\subsection{Research Questions}

In this part, the writers discuss the research finding of two objectives of the study. They are (1) to find out the types of illocutionary acts used by Arthur in Joker movie and (2) to find out the dominant types of illocutionary acts used by Arthur in Joker movie and what that means. To answer the objectives of the study, the writers divided it into two sections. First was to find the types of illocutionary act, second was the dominant types of illocutionary acts used by Arthur in Joker movie and what does that mean. The findings of this study were as follows:

\subsubsection{The Types of Illocutionary Acts}

In this section, the writers present the table of illocutionary acts used by Arthur in Joker movie. The table is displayed through the frequency of the illocutionary appeared. The utterances are also provided in each finding of illocutionary types to show the example of utterances spoken by the character of Arthur. The findings are presented as follow:

Table 1. Illocutionary Act Types

\begin{tabular}{ccl}
\hline $\begin{array}{c}\text { Types of } \\
\text { Illocutionary Acts }\end{array}$ & Frequency & \multicolumn{1}{c}{ Example of the utterances } \\
\hline Assertives & 8 & $\begin{array}{l}\text { Maybe you shouldn't watch so much television. } \\
\text { I should have killed myself. }\end{array}$ \\
Directives & $27 \quad \begin{array}{l}\text { I was wondering if you could ask the doctor to } \\
\text { increase the dosage on my medications? } \\
\text { Why are these letters so important to you, Ma? } \\
\text { What do you think he's gonna do? } \\
\text { If I were you, I'd walk away from this table before } \\
\text { I strangle all three of you with that fucking } \\
\text { stethoscope hanging from your neck. }\end{array}$ \\
& $\begin{array}{l}\text { They wouldn't let me see him. (lying) But they } \\
\text { promised me it would get to him. } \\
\text { I'm a fuck up and I'm fired. } \\
\text { I'm a fuck up and I'm fired. } \\
\text { They said I wasn't funny. (opposing) }\end{array}$
\end{tabular}


Expressives

Declaratives

$9 \quad$ My mother says that the people nowadays lack empathy.

How come nothing ever comes easy for me?

\begin{tabular}{ll}
4 & YOU KNOW WHAT?! I FORGOT MY ID! I'LL BE \\
Declaratives & BACK. THANK YOU. \\
& Apparently I'm Thomas Wayne's son! \\
\hline Total & 52 utterances \\
\hline
\end{tabular}

Based on the table above, there are 52 utterances found and categorized as illocutionary acts. The illocutionary types found are assertives, directives, commisives, expressives, and declaratives. There are 8 utterances categorized as assertives, 27 utterances categorized as directives, 4 utterances categorized as commissive, 9 utterances categorized as expressives, and 4 utterances categorized as declaratives. Directive was the dominant type found in Arthur's utterances. Directive mostly used by the characters in their conversation as it pointed directly to another person he talked with. Directive is an utterance where it represents asking, ordering, requesting, and inviting. The examples of the utterance of directive by Arthur are stated as follows:

$$
01: 18: 48,500 \rightarrow 01: 18: 51,560
$$

Arthur: Why are these letters so important to you, Ma? What do you think he's gonna do?

$$
01: 18: 51,570 \rightarrow 01: 18: 53,070
$$

Arthur's Mother: Maybe he can help us.

$$
01: 18: 48,500 \rightarrow 01: 18: 51,560
$$

Arthur: You worked for him over 30 years ago. What makes you think he would help you?

Based on the example above, in minute 01:18:48, where Arthur talked to his mother, he asked her mother why she was desperate to send a letter to Mr. Wayne. That conversation showed Arthur directly asking her mother face to face and nothing implied.

\subsubsection{The dominant types of illocutionary acts used by Arthur in Joker movie and what they mean.}

In this section, the writer displayed the table of dominance and figure of dominance. The dominant types of illocutionary are also explained after the table and the dominance chart 
displayed. The explanation is divided to each illocutionary types (from the most dominant to the least dominant) as follow:

Table 2. The Dominance of Illocutionary Types

\begin{tabular}{cccc}
\hline No & Types of Illocutinary Acts & Frequency & Precentages \\
\hline 1 & Assertives & 8 & $15 \%$ \\
2 & Directives & 27 & $51 \%$ \\
3 & Commissives & 4 & $7,6 \%$ \\
4 & Expressives & 9 & $17,3 \%$ \\
5 & Declaratives & 4 & $7,6 \%$ \\
\hline & Total & 52 & $100 \%$ \\
\hline
\end{tabular}

Based on the table above, directive got the most percentage which means it was the most dominant type. Followed by expressive as the second most dominant type, then assertive as the third dominant type, commissive and declarative were the least dominant type. However, to prove that directive was the most dominant type, the writer displayed chart of dominance states as follows:

Figure 1. The Chart of Dominance

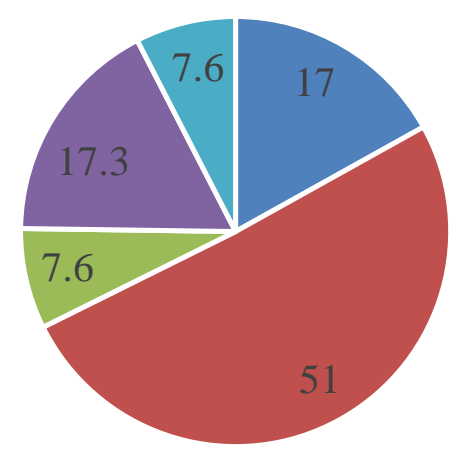

\footnotetext{
- Assertives - Directives $\quad$ Commissives

- Expressives - Declaratives
} 
Based on the chart above, the red-colored shape which is directive type dominated the chart. The second dominant type was a purple-colored shape which is expressive. Then the other three (assertive, commissive, and declarative) did not show any gaps. Furthermore, the writer provided an explanation of the reasons why directive is the most dominant type, expressive as the second, and declarative as the least dominant type in this study. The explanation will be elaborated below.

\subsubsection{Directive type as the most dominant}

From the data in research finding, directive is the most dominant type that is commonly used by Arthur in Joker (2019) movie. The reason is the common use of directive to represent asking, ordering, requesting, inviting, advising, and begging by Arthur in the movie. As in this movie, Arthur frequently talks directly to the other characters. Here, the examples when he is talking directly to his psych doctor:

SOCIAL WORKER : Is there something else I can help you with, Arthur? My next appointment is waiting.

JOKER : Yeah, I was wondering if you could ask the doctor to increase the dosage on my medications? Nothing seems to make a difference.

From the example above, Arthur had his regular appointment with a psychiatrist due to his mental health. He had a condition where he could not stop laughing even though there was nothing funny and that condition had upset him for his whole life. It later carries his mental anxiety. Therefore, he needed to see a psychiatrist to keep him sane. That example of conversation is directive illocutionary.

\subsubsection{Expressive type as the second most dominant}

Expressive type of illocutionary acts represents thanking, apologizing, welcoming, and deploring. As in this movie, Arthur always apologizes whenever his laughs burst out. Whenever people asked him What's the funny thing about? Arthur would reply with I'm sorry I have a condition and gave his mental card to the interlocutor.

\subsubsection{Assertive type as the third most dominant}

The reason why assertive is commonly used was as it is represented suggesting, putting forward, swearing, boasting, and concluding. As in this movie, Arthur frequently boasted about himself. Here is the example:

JOKER/Arthur : Why didn't Randall tell me the gun was loaded? He's my friend. With my luck, I could have killed someone. I could have killed myself.

JOKER/Arthur $\quad$ : (still to himself) I should have killed myself.

JOKER/Arthur : : (louder to himself) I should kill myself. 
The situation above happened when Arthur clicked the gun Randal gave him. Arthur did not know that the gun was loaded (real gun) and he was shocked when it was the real gun. With a real gun in his hands, he could kill himself because his mental illness always overcome his thoughts.

\subsubsection{Commissive type as the fourth dominant}

Commissive type of illocutionary acts represents promising, planning, vowing, betting, and opposing. As in this movie, Arthur usually utters an opposed answer when he gives some questions. Here is the example when Arthur is lying (and opposing) to his mother:

Mother :--so what did he says when you gave him the letter?

Joker/Arthur : : They wouldn't let me see him. (lying) But they promised me it would get to him.

Mother : It's good they promised. He only works with the best. We should hear something soon.

(Arthur does not reply, instead he fills an empty plastic container with some bath water.)

Based on the example above, Arthur opposes his mother with a silent reply and is lying to his mother that the staff in Wayne's mansion would give her letter to Mr. Wayne directly when it certainly is not. That's an example of commissive.

\subsubsection{Declarative type as the least dominant}

Declarative, as a type of illocutionary acts represents both directive and commissive type. It usually is repetition of giving suggestion and order, or ordering multiple times. The characters usually use declarative when they were in a very danger situation or an annoyed situation or when he wanted the opposite person to talk to him. For example here is when Arthur used declarative sentence when he found out that he is Wayne's son:

JOKER /Arthur : : Apparently I'm Thomas Wayne's son! How could you keep that from me?

Mother $\quad$ : Stop yelling at me, you're gonna kill me, give me a heart attack!

JOKER/Arthur : (shouts after her) I'm not yelling! I'm just, excited. How can any of this be real!? How can Thomas Wayne be my father?

In the example above, Arthur increased his tone in talking as if he declares that he is shocked and excited. He got to know that he is Wayne's son, the son of the great Thomas Wayne. Thus is the example of declarative (to declare) that was used by Arthur in the Joker movie.

The difference between this study and the previous study stated above is that this research used movie as an object and focused on the main characters' utterances. This, research looked for the dominant speech acts used by the object of the study while the 
previous study did not. The purpose of using movie as an object of the study is because people will get real examples of the use of speech acts and know the gesture while saying that.

\section{Conclusion}

In conclusion, based on the study, the writer discussed the research findings in two sections. The first section discussed the finding of the types of illocutionary acts used by Arthur in Joker movie and the second discussed the finding of the dominant types of illocutionary acts used by Arthur in Joker movie and what that means.

The result of data finding on the first section was displayed into table 4.1. Based on the table, there are 52 utterances found that are categorized as illocutionary types. The illocutionary types found are assertives, directives, commisives, expressives, and declaratives. There are 8 utterances categorized as assertives type, 27 utterances categorized as directives type, 4 utterances categorized as commissive type, 9 utterances categorized as expressives type, and 4 utterances categorized as declaratives type. Directive type was the dominant type found in Arthur's utterances.

The dominant of Arthur's utterances were the result of data finding on the second section. It was shown in table 4.2 and figure 4.1. In table 4.2, directive illocutionary type got the most percentage which means it was the most dominant type. Followed by expressive as the second most dominant type, then assertive as the third dominant type, commissive and declarative were the least dominant type. Then it was shown in figure 4.1, the red-colored shape which is directive type dominated the chart. The second dominant type was a purplecolored shape which is expressive. Then the other three (assertive, commissive, and declarative) did not show any gaps.

The reason why directive dominates Arthur's speech is because Arthur had his regular appointment with a psychiatrist due to his mental health. He had a condition where he could not stop laughing even though there is nothing funny about him. And that condition had upset him for his whole life. It later carries his mental anxiety. Therefore, he needed to see a psychiatrist to keep him sane. The conversation he took with his psychiatrist is a directive type of illocutionary.

The writers recommend to the future researchers to use other objects, such as song, novel, or another movie in this study. The weaknesses that the writers had in conducting this research are slow speed of the internet connection therefore it took much time to download the movie and the writers need more time in classifying the utterances from the movie script.

\section{References}

Alek., Hausca., Hidayat., \& Marzuki. (2020). Illocutionary speech acts analysis in Tom Cruise's interview. Academia Journal Perspective: Language Education and Literature. http://jurnal.ugj.ac.id/index.php/Perspective/article/view/3304

Andayani., Biduasih., \& Rohmadi. (2016). Illocutionary acts on speech of foreign students in Indonesia learning. Linguistics and Education, 6(2). http://ejournal.undip.ac.id/index.php/parole 
Azhari, A. S., Priono., \& Nuriadi. (2018). Speech acts of classroom interaction. International Journal of Linguistics, Literature, and Culture.

Creswell, J. W. (2014). Research design: qualitative, quantitavive, and mixed methods approaches (4th ed). Sabe.

Diani, G. (2008). Emphasizers in spoken and written academic discourse: The case of reality. International Journal of Corpus Linguistics, 13(3), 296-321.

Emmiyati, N. (2012). Illocutionary acts in "Midnight in Paris" Movie. English and Literature Department, Faculty Of Adab and Humanities, Alauddin State Islamic University of Makassar. http://journal.uin-alauddin.ac.id/index.php/elite/article/view/3385

Hidayat, A. (2016). Speech acts: Force behind words. English Education: Journal Tradis Bahasa Inggris.

Kach, B. (2013). Communication in the real world: An introduction to communication studies. University of Minnesota Libraries Publishing edition.

Martin, J. R., D. (2003). Working with discourse; meaning beyond the clause. Continuum.

Martin, J. R., D. (2007). Working with discourse; meaning beyond the clause (3rd ed.). Continuum.

Martinez, J. (2015). The speech act as an act of knowing. International Journal of Language and Linguistics.

Nick, R. (2010). Introducing on linguistics and semantics (3rd ed.). Cambridge University Press.

Petriady, D. (2018). Illocutionary acts found in novel the never girls: Before the Bell By Kiki Thorpe. English Language and Literature Padang University, 7(1). http://ejournal.unp.ac.id/index.php/ell/article/view/8799/7247

Santosa, R. (2009). Genre in discourse. Universitas Sebelas Maret Surakarta.

Santosa, R. (2009). Logic of discourse. Universitas Sebelas Maret Surakarta.

Searle, J. (2002). Conciousness and language. Cambridge University Press.

Sembiring, W. (2019). Illocutionary acts on Alladin movie. Universitas Putera Batam, 6(2).

http://ejournal.upbatam.ac.id/index.php/basis/article/download/1419/883

Siritman, B., \& Meilantina, M. (2020). English speech acts of directives in class interaction. International Journal of Language Education and Culture Review. 


\section{Appendix}

\begin{tabular}{|c|c|c|c|c|c|}
\hline & Assertives & Directives & Commissives & Expressives & $\begin{array}{c}\text { Declarative } \\
\text { s }\end{array}$ \\
\hline $\begin{array}{l}\text { Exa } \\
\text { mple }\end{array}$ & $\begin{array}{l}\text { These speech acts } \\
\text { include stating, } \\
\text { claiming, } \\
\text { hypothesizing, } \\
\text { describing, telling, } \\
\text { insisting, suggesting, } \\
\text { asserting, swearing, } \\
\text { statements of fact. } \\
\text { Example: } \\
\text { - The earth is } \\
\text { flat. } \\
\text { didn't write about } \\
\text { peanuts. }\end{array}$ & $\begin{array}{l}\text { These speech } \\
\text { acts include } \\
\text { requesting, } \\
\text { questioning, } \\
\text { advising, } \\
\text { ordering, asking, } \\
\text { advising, } \\
\text { commanding, } \\
\text { and defying. } \\
\text { Example : } \\
\text { • Could } \\
\text { you lead me a } \\
\text { pencil, please? } \\
\text { • Don't } \\
\text { touch that! }\end{array}$ & $\begin{array}{l}\text { These speech } \\
\text { acts include } \\
\text { promising, } \\
\text { threatening, } \\
\text { offering, refusal, } \\
\text { pledges. } \\
\text { Example: } \\
\text { • I'll be } \\
\text { there at } 10 \\
\text { o'clock } \\
\bullet \quad \text { I'll give } \\
\text { you } 5 \text { dollars } \\
\text { for the watch } \\
\bullet \quad \text { I } \\
\text { promise to } \\
\text { exercise every } \\
\text { day }\end{array}$ & $\begin{array}{l}\text { These speech } \\
\text { acts include } \\
\text { thanking, } \\
\text { apologizing, } \\
\text { welcoming, and } \\
\text { congratulating. } \\
\text { Example: } \\
\text { - Thank } \\
\text { you for giving } \\
\text { me the money } \\
\text { - Congrat } \\
\text { ulation on } \\
\text { your } \\
\text { graduation. }\end{array}$ & $\begin{array}{l}\text { These } \\
\text { speech acts } \\
\text { include } \\
\text { excommunic } \\
\text { ating, } \\
\text { declaring } \\
\text { war, } \\
\text { christening, } \\
\text { firing from } \\
\text { employment. } \\
\text { Example : } \\
\text { - Yo } \\
\text { u are dead } \\
\text { me. }\end{array}$ \\
\hline 1 & $\begin{array}{l}\text { We need a new game } \\
\text { plan. }\end{array}$ & $\begin{array}{l}\text { is it just me, or is } \\
\text { it getting crazier } \\
\text { out there? }\end{array}$ & $\begin{array}{l}\text { They wouldn't let } \\
\text { me see him. } \\
\text { (lying) But they } \\
\text { promised me it } \\
\text { would get to him. }\end{array}$ & $\begin{array}{l}\text { My mother says } \\
\text { that the people } \\
\text { nowadays lack } \\
\text { empathy. }\end{array}$ & $\begin{array}{l}\text { YOU } \\
\text { KNOW } \\
\text { WHAT?! I } \\
\text { FORGOT } \\
\text { MY ID! I'LL } \\
\text { BE BACK. } \\
\text { THANK } \\
\text { YOU. }\end{array}$ \\
\hline 2 & $\begin{array}{l}\text { Last time I ended up } \\
\text { taking it out on some, } \\
\text {.. people. Bad shit. I } \\
\text { though it would } \\
\text { bother me but, it } \\
\text { really hasn't. }\end{array}$ & $\begin{array}{l}\text { I was wondering } \\
\text { if you could ask } \\
\text { the doctor to } \\
\text { increase the } \\
\text { dosage on my } \\
\text { medications? } \\
\text { Nothing seems } \\
\text { to make a } \\
\text { difference. }\end{array}$ & $\begin{array}{l}\text { I'm a fuck up and } \\
\text { I'm fired. } \\
\text { I'm a fuck up and } \\
\text { I'm fired. }\end{array}$ & $\begin{array}{l}\text { It means like } \\
\text { "feeling for other } \\
\text { people." }\end{array}$ & $\begin{array}{l}\text { Apparently } \\
\text { I'm Thomas } \\
\text { Wayne's } \\
\text { son! How } \\
\text { could you } \\
\text { keep that } \\
\text { from me? }\end{array}$ \\
\hline 3 & $\begin{array}{l}\text { Maybe you shouldn't } \\
\text { watch so much } \\
\text { television. }\end{array}$ & $\begin{array}{l}\text { I just don't } \\
\text { wanna feel so } \\
\text { bad anymore. }\end{array}$ & $\begin{array}{l}\text { Not for having a } \\
\text { gun. That was } \\
\text { prop gun. Part of } \\
\text { my act. }\end{array}$ & $\begin{array}{l}\text { Hi. Do you like } \\
\text { to laugh? }\end{array}$ & $\begin{array}{l}\text { I'm not } \\
\text { yelling! I'm } \\
\text { just, excited. } \\
\text { How can } \\
\text { any of this } \\
\text { be real!? } \\
\text { How can } \\
\text { Thomas } \\
\text { Wayne be } \\
\text { my father? }\end{array}$ \\
\hline
\end{tabular}




\begin{tabular}{|c|c|c|c|c|c|}
\hline 4 & $\begin{array}{l}\text { Why didn't Randall } \\
\text { tell me the gun was } \\
\text { loaded? He's my } \\
\text { friend. With my luck, } \\
\text { I could have killed } \\
\text { someone. (beat) I } \\
\text { could have killed } \\
\text { myself. }\end{array}$ & $\begin{array}{l}\text { How you feeling } \\
\text { today? }\end{array}$ & $\begin{array}{l}\text { They said I } \\
\text { wasn't funny. }\end{array}$ & $\begin{array}{l}\text { Remember how } \\
\text { I told you that } \\
\text { I'm a stand-up } \\
\text { comedian? } \\
\text { (again) Hi. How } \\
\text { are you? }\end{array}$ & $\begin{array}{l}\text { Happy?! I'm } \\
\text { not happy. I } \\
\text { haven't been } \\
\text { happy for } \\
\text { one minute } \\
\text { of my entire } \\
\text { fucking life. }\end{array}$ \\
\hline 5 & $\begin{array}{l}\text { I should have killed } \\
\text { myself. (slower) }\end{array}$ & $\begin{array}{l}\text { Why are these } \\
\text { letters so } \\
\text { important to you, } \\
\text { Ma? What do } \\
\text { you think he's } \\
\text { gonna do? }\end{array}$ & & $\begin{array}{l}\text { How come } \\
\text { nothing ever } \\
\text { comes easy for } \\
\text { me? }\end{array}$ & \\
\hline 6 & $\begin{array}{l}\text { I should have killed } \\
\text { myself. (louder) }\end{array}$ & $\begin{array}{l}\text { You worked for } \\
\text { him over } 30 \\
\text { years ago. What } \\
\text { makes you think } \\
\text { he would help } \\
\text { you? }\end{array}$ & & & \\
\hline 7 & $\begin{array}{l}\text { Yeah,-- I don't know } \\
\text { how something like } \\
\text { that happens. }\end{array}$ & $\begin{array}{l}\text { What do you } \\
\text { mean? }\end{array}$ & & & \\
\hline 8 & $\begin{array}{l}\text { But you know what's } \\
\text { funny? You know } \\
\text { what really makes me } \\
\text { laugh? I used to think } \\
\text { my life was nothing } \\
\text { but a tragedy, but } \\
\text { now, now I realize it's } \\
\text { all just a fucking } \\
\text { comedy. }\end{array}$ & $\begin{array}{l}\text { Randall told you } \\
\text { that? }\end{array}$ & & & \\
\hline 9 & & Say what? & & & \\
\hline 10 & & $\begin{array}{l}\text { Were you } \\
\text { crying? Why are } \\
\text { you crying? }\end{array}$ & & & \\
\hline 11 & & $\begin{array}{l}\text { How am I gonna } \\
\text { get my } \\
\text { medication? }\end{array}$ & & & \\
\hline 12 & & $\begin{array}{l}\text { Why are they } \\
\text { talking to him? }\end{array}$ & & & \\
\hline 13 & & $\begin{array}{l}\text { Hey. You want } \\
\text { to get some } \\
\text { coffee? }\end{array}$ & & & \\
\hline 14 & & What happened? & & & \\
\hline 15 & & $\begin{array}{l}\text { With your job. } \\
\text { At the bank? }\end{array}$ & & & \\
\hline
\end{tabular}




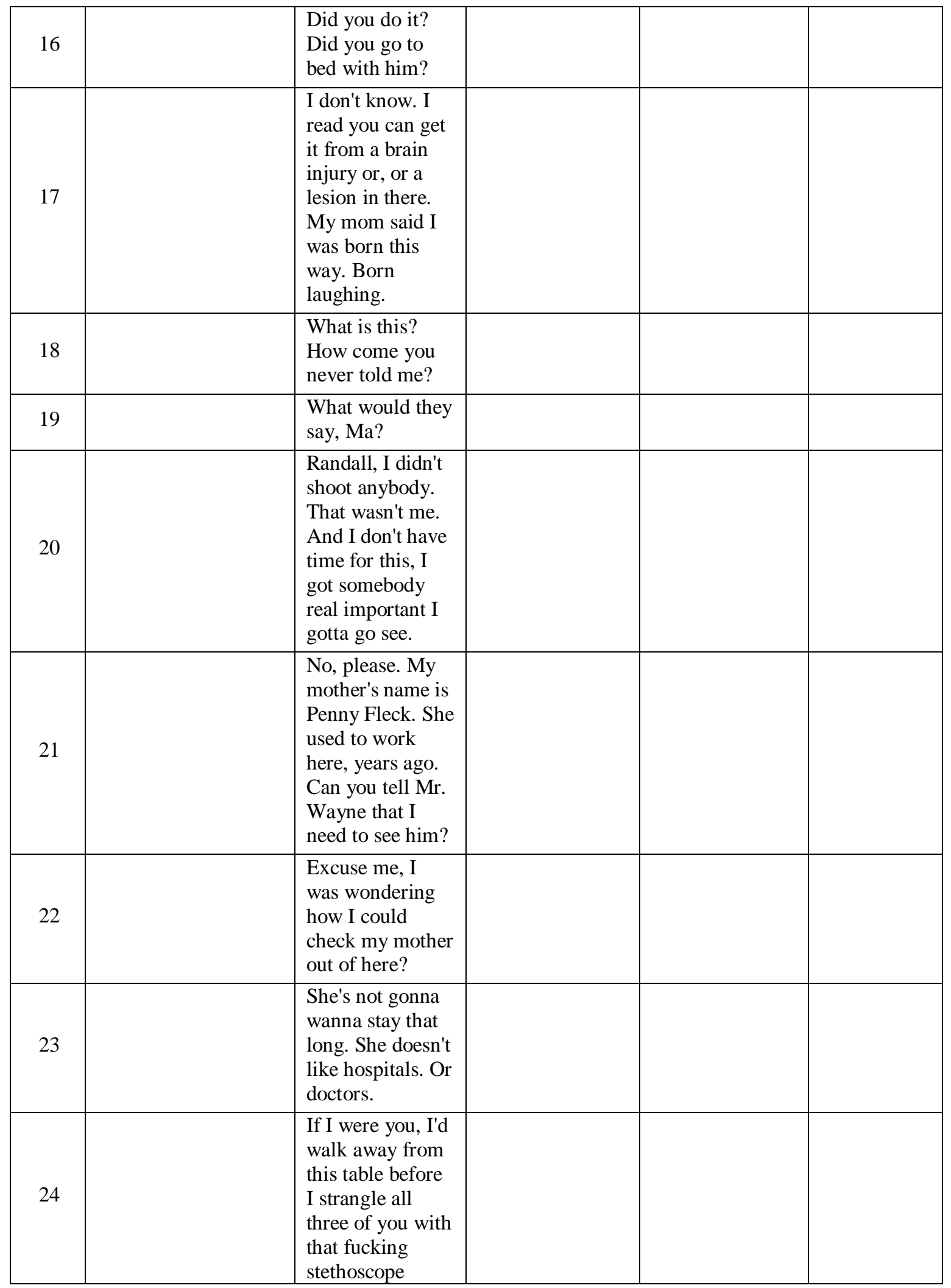




\begin{tabular}{|c|l|l|l|l|l|}
\hline & $\begin{array}{l}\text { hanging from } \\
\text { your neck. }\end{array}$ & & & \\
\hline 25 & & $\begin{array}{l}\text { You wanna hear } \\
\text { a joke, Murray? }\end{array}$ & & & \\
\hline 26 & $\begin{array}{l}\text { Go on. Go. } \\
\text { You're free. }\end{array}$ & & & \\
\hline 27 & $\begin{array}{l}\text { It's okay, Gary. } \\
\text { You can go. }\end{array}$ & & & \\
\hline
\end{tabular}

